\title{
El Código Civil de Andrés Bello: Su lectura por la Iglesia Católica
}

\author{
José Antonio González Pizarro*
}

\begin{abstract}
"A diferencia de los sabios que prepararon la catástrofe que inundó a Francia en lágrimas y sangre, el sabio americano no venía a levantar el edificio del progreso intelectual sobre los escombros de la fe: venía a levantar ese edificio sobre la única base en que puede ser consistente y grande: la ciencia hermanada con la religión".

El Estandarte Católico, Santiago, 26 de noviembre de $1881^{1}$.
\end{abstract}

RESUMEN: El artículo examina el contexto bistórico en el cual se revisó y entró en vigencia el Código Civil chileno. Para tal efecto, el trabajo se divide en dos partes: una primera se centra en las impresiones que causó el Código Civil entre los obispos chilenos en el año 1856 y una segunda se centra en las concordancias llevadas a cabo desde la Teología Moral con el Código Civil, donde la Iglesia dejó impresas sus diferencias, precisamente, procedentes desde el Derecho Canónico y la Teología Moral.

Palabras clave: Código Civil - Teología Moral - Iglesia - Estado - Chile.

\section{The Civil Code of Andrés Bello: Its reading by the Catholic Church}

ABSTRACT: The article reviews the historic context when the Chilean Civil Code was revised and came into force. For this purpose, the essay is divided in two parts: a first one focused in the impressions

\footnotetext{
Doctor en Historia por la Universidad de Navarra, España. Profesor Historia del Derecho, Escuela de Derecho Universidad Católica del Norte, Antofagasta (CHILE). Correo electrónico: jagonzalez@ucn.cl

Artículo recibido el 12 de enero de 2006. Aprobado por el Comité Editorial el 26 de junio de 2006.

1 Cf. Comisión Nacional de conmemoración de la muerte de Andrés Bello: La prensa chilena y la codificación 1822-1878, Introducción y recopilación de Guillermo Feliz Cruz, Santiago, Universidad de Chile, 1966, 242.
} 
caused by the Civil Code between the Chilean bishops in the year 1856, and a second focused in the agreements carried out from the Moral Theology with the Civil Code, where the Church imprinted its differences proceeding precisely from the Canon Law and the Moral Theology.

\author{
Key words: Civil Code - Moral Theology - Church - State \\ - Chile.
}

SUMARIO: I. Introducción. II. Las observaciones de la jerarquía eclesiástica al Código Civil en 1856. III. La lectura del Código Civil desde la Teología Moral, como expresión de la concordancia entre la ley civil y los preceptos eclesiásticos. IV. Conclusión.

\title{
I. INTRODUCCIÓN
}

Durante la larga administración de Manuel Montt, que entera el decenio de 1850 , se verificaron varios acontecimientos que afectaron las relaciones Iglesia y Estado. La Iglesia y el Estado estaban unidos bajo el régimen del patronato que traducía una serie de deberes y obligaciones recíprocas. No obstante, este encuadre constitucional, que proyectaba la confesionalidad del Estado y la influencia eclesiástica en determinadas esferas de la vida pública, no estuvo ajeno a determinados desafíos que se dieron bajo el gobierno de Montt.

Uno de los desafíos giró en torno al juramento civil de los obispos chilenos, que motivó, en 1854 , la intervención del Papa Pío IX ${ }^{2}$.

El más difícil para la sociedad chilena, y el más agudo conflicto para la Iglesia y el Estado, fue el denominado por la historiografía y

2 El Papa Pío IX, a indicación del propio Valdivieso, condenó el juramento civil de los obispos, en carta del 6 de julio de 1854 , censurando de paso lo obrado por el segundo arzobispo de Santiago:

"El juramento prestado por ti debe tenerse por absolutamente ilícito y nulo, porque en la fórmula de dicho juramento no solo se promete reconocer el derecho de patronato, que pretende gozar ese gobierno respecto de los beneficios eclesiásticos y del cual enteramente carece, pues jamás se le ba concedido tal privilegio por esta Sede Apostólica, sino que, además, se promete por la expresada fórmula, no dar cumplimiento a las disposiciones de los sumos pontífices, sin la venia o exequatur de la potestad civil, lo que es de todo punto contrario al Supremo Primado de orden y jurisdicción que por derecho divino tiene el Romano Pontífice en toda la Iglesia. Por esto, venerable bermano, ciertamente comprenderás que es completa y absolutamente malo (nefas omnino) prestar el referido juramento" La cita proviene de Aravena Bravo, Fidel: Historia de la Iglesia en Chile, Ediciones Paulinas, Santiago, 1986, 468. El arzobispo Valdivieso dio a conocer esta misiva a los demás obispos en septiembre de 1858. El asunto ha sido examinado por ARTEAGA, José: 
la prensa como la "cuestión del sacristán", que discurrió entre enero y octubre de 1856. El asunto llevó a que en un momento dado se temiere que el arzobispo Valdivieso pudiere afectarle una pena de extrañamiento, a causa de su negativa de acatar un fallo de la Corte Suprema a favor de un par de canónigos que habían acudido al "recurso de fuerza"3.

Durante el mandato de Montt la figura eclesiástica dominante fue el arzobispo de Santiago D. Rafael Valentín Valdivieso ${ }^{4}$.

Los hechos mencionados nos auxiliarán para comprender el "ambiente" que se vivía en los círculos católicos cuando se discuta el Código Civil, redactado por Andrés Bello.

Nuestro trabajo se centra, entonces, en la acogida del Código Civil por parte de la Iglesia. Tal recepción puede dividirse en dos niveles: un primer nivel, dice relación con las impresiones por parte de la jerarquía eclesiástica de los contenidos del Código Civil, donde en la correspondencia mantenida entre los obispos, se manifestó la discrepancia respecto a materias que la Iglesia consideró sensibles o que lastimaban su potestad; un segundo nivel fue lo expresado desde la Teología Moral respecto al Código Civil. Disciplina que se enseñaba en la formación doctrinal impartida en el Seminario y que, en el caso que nos ocupa, se tradujo en una serie de manuales donde se divulgó la postura eclesial sobre los contenidos de la ley secular.

\section{Las observaciones de la jerarquía eClesiástica al Código CIVIL EN I 856}

El gobierno de Manuel Montt, mediante el decreto de 26 de octubre de 1852 , nombró una comisión para que revisara el proyecto

"Gobierno como electo y juramento civil del Arzobispo R. Valentín Valdivieso, 18451848", Anales de la Facultad de Teologia, Pontificia Universidad Católica de Chile, volumen XXVII, Cuaderno I, Año 1976, pp.1-161. La documentación pertinente se puede consultar en Retamal Fuentes, Fernando: Chilensia Pontificia. Primera Parte. De Pío IV a Pío IX (1561-1878) Ediciones Universidad Católica de Chile, 1998, Volumen I/Tomo II, pp. 526-586.

3 Una publicación contemporánea, Relación documentada de la expulsión de un sacristán de la Iglesia Metropolitana de Santiago de Chile, $i$ del recurso de fuerza entablado por el Arcediano i Doctoral de la misma, Imprenta de la Sociedad, Santiago, abril de 1857, concluía con estas significativas palabras la gravedad suscitada: "Puestas las cosas en el estado en que se encontraban cuando se acudió al desistimiento de los Prebendados, el destierro del señor Arzobispo no podría ya ejecutarse sin que el Gobierno se hubiera constituido en perseguidor declarado de la Iglesia, i sería una ilusión manifiesta creer que podía hacerse durar en Chile un estado tan opuesto a sus convicciones, a sus habitudes i a sus más respetadas tradiciones" (p. 280).

4 Para un conocimiento general de su pensamiento teológico y su relación con el Estado, remito al estudio de ARTEAGA Llona, José "Rafael Valentín Valdivieso y Zañartu (18041878)" en Arteaga L., José (dir): Pensamiento Teológico en Chile. Contribución a su estudio. II. Época de la reorganización y consolidación eclesiásticas, 1840-1880. Facultad de Teología, Universidad Católica de Chile, Santiago, 1982, pp 184-210. 
de Código Civil de Andrés Bello e informara sobre la obra. Para dar cumplimiento a esto se distribuyó una impresión del proyecto para ser entregado a los "miembros de los tribunales superiores de justicia, a los jueces de letras y a los integrantes de la facultad de leyes de la Universidad "para que informen sobre él, haciendo las observaciones que su examen les sugiera" 5 .

Llama la atención que determinados miembros de la Comisión, como Manuel Antonio Tocornal, que defendió las prerrogativas del arzobispo Valdivieso ante la Corte Suprema en la "cuestión del sacristán", no expresaran las inquietudes de la Iglesia respecto a puntuales asuntos que pudieron ser estimados como lesivos a sus facultades en el nuevo cuerpo legal.

La postura eclesial ante el Código Civil fue de absoluta observancia y sus reparos muy específicos. Y esta se manifestó desde el 14 de diciembre de 1855, cuando fue promulgado el Código, y más aún a contar del 1 de enero de 1857 , cuando entró en vigencia. No obstante, hay determinados elementos en los reparos aludidos que merecen un tratamiento especial. Fueron muy significativos cuando los ventiló la principal autoridad eclesiástica con el obispo de Concepción. De su epístola se desprende una visión totalizadora del momento donde las tensiones políticas, de las que hemos hecho mención, quedan de trasfondo. Denota una desconfianza respecto del avance de las posiciones que él calificará de "regalistas" o del afianzamiento del Poder Ejecutivo respecto a competencias que eran consideradas exclusivas de la Iglesia. A nuestro entender, desvela un "modo" de ser católicos, en un sector importante de la sociedad ilustrada, que el arzobispo percibe con mucha perspicacia.

La lectura del Código Civil por parte del arzobispo de Santiago le condujo a convencerse del influjo ideológico europeo en lo concerniente al rumbo de la sociedad chilena en general. Asumió la profunda influencia de algunas ideas secularizadoras en las mentes de los legisladores nacionales. Y, en definitiva, la constatación que puntuales artículos del Código estaban en total desacuerdo con lo establecido por la doctrina y el derecho eclesiástico.

¿Cómo poder visualizar estos tres niveles a los que se ciñe la mirada de monseñor Rafael Valentín Valdivieso? Comparando sus comunicaciones dirigidas a los obispos de Concepción y La Serena, donde descubre lo recóndito de su pensamiento y habla -porque el género epistolar lo permite-con toda franqueza de sus prevenciones. Estas cartas se pueden

Guzmán Brito, Alejandro: Andrés Bello codificador. Historia de la fijación y codificación del derecho civil en Chile, Ediciones de la Universidad de Chile, Santiago, 1982, Tomo I, 370 . 
cotejar con los contenidos -más medidos políticamente hablando- que los tres prelados dirigen al Senado.

Puede captarse en estas misivas la mejor "sintonía" que tuvo con el obispo José Hipólito Salas que con el obispo Justo Donoso. Este último una autoridad en el Derecho Canónico.

Entre los días 28-29 de julio, fechas en que el arzobispo envió las cartas, y el 24 de septiembre de 1856 , en que los tres obispos se dirigen al Senado, podemos apreciar un cambio en pro de una argumentación más sólida, en cuanto a las fuentes eclesiásticas aducidas y, también, una disminución del rasgo "político" en el espíritu del arzobispo Valentín Valdivieso.

Comparemos las líneas liminares dirigidas por monseñor Valentín Valdivieso a ambos.

Al obispo de Concepción, al que le escribió el 28 de julio de 1856 , le indica:

"Supongo que Ud. babrá estudiado el Código Civil que sancionó el Congreso a fines del año pasado, que debe comenzar a regirnos el $1^{\circ}$ de enero de 1857. Quiero que mutuamente nos comuniquemos las observaciones que nos ocurran, i en virtud de ellas, resolvamos si conviene, ejercitando el derecho de petición, hacer algunas a las Cámaras sobre este particular.

La lectura del dicho Código me ba becho formar juicio de que en lo relativo a la religión i a la Iglesia descansa en sólidos principios, pero que se resiente de las prevenciones del siglo en la aplicación de esos mismos principios, a varias cosas sobre que versan sus disposiciones.

Sus autores semejan a ciertos sujetos que pasan por mui católicos, pero que, como regalistas, se extasían con los Condes de Aranda i Campomanes, i como políticos, admiran las conquistas de la revolución francesa i las aplauden_[Destacados míos]. Para explicarme, voi a detallar a Ud., los principales artículos que no encuentro buenos" 6 .

Al obispo de La Serena, a quien escribe al día siguiente, 29 de julio, le omite lo trascrito y le asevera:

“Ante todo, cumple a mi deber reconocer que el Código tributa sus respetos a los sanos principios, i no parece que quiere atropellar a la Iglesia; mas, esto mismo bace desear que desaparezcan de el algunos lunares"7.

6 "Al Ilmo. Sr. Obispo de Concepción, Santiago, julio 28 de 1856", en Obras Científicas $i$ Literarias del Ilmo. Y Rmo. Sr. Don Rafael Valentín Valdivieso, Arzobispo de Santiago de Chile. Recopiladas por José Ramón AstorgA, obispo de Martirópoli, Imprenta, Litografía i Encuadernación Barcelona, Santiago, 1902, Tomo II, 8. La epístola corre entre pp. 7-23. "Al Ilmo. Sr. Obispo de La Serena, Santiago, julio 29 de 1856", en Obras Científicas i Literarias del llmo y Rmo Sr. Don Rafael Valentín Valdivieso, op. cit. Tomo II, 23. La carta se encuentra entre páginas 23-27. 
En la carta colectiva dirigida al Senado apelan al derecho establecido en la parte $6^{a}$ del artículo 12 de la Constitución y, en consecuencia, trasladan las observaciones desprendidas de la lectura del Código:

"Sobre algunas de sus disposiciones que tienen relación con los intereses sagrados, los cuales están confiados a nuestra pastoral solicitud. Estamos distantes de pretender acercarnos en capacidad $i$ saber a los acreditados jurisconsultos que han formado i examinado el Código, pero, la experiencia que el ejercicios mismo de nuestro ministerio nos ba becho adquirir en las materias sobre que versan nuestras observaciones, nos permite llamar la atención de la Cámara.

Ella debe convencerse de que solo abrigamos el deseo de que la obra de los Legisladores sea la más perfecta posible $i$ adecuada a nuestras necesidades; $i$ de que la justificada i respetuosa franqueza con que se han proclamado $i$ sancionado en el Código los principios católicos, no ba contribuido poco a alentar la confianza que tenemos, de que se corregirán algunas aplicaciones remotas de sus mismos principios... encontramos que puede darse lugar a que se hagan valer contra los intereses verdaderos de la Iglesia, de la sociedad, cosas que seguramente no ba querido ni previsto el legislador"8.

Seguiremos el planteamiento expuesto al obispo de Concepción. En él, hallaremos una explanación amplia tanto en lo específico de algún artículo del Código, al ser cotejado con las disposiciones eclesiásticas, como observaciones sobre las intenciones de los legisladores y los inconvenientes de la aplicación de algunos artículos dados las condiciones de nuestra realidad social. Seguidamente, consignaremos lo elevado a los senadores de modo conjunto por los tres obispos.

El primer tema fue lo concerniente a los impedimentos matrimoniales. Si bien el Título IV del Libro I reconocía la competencia exclusiva de la Iglesia en la materia, reparaba que el artículo 104 comenzaba con los "resabios":

"El artículo 104 declara que el matrimonio, entre afines de la línea recta, aunque haya sido dispensado por la autoridad eclesiástica, no produce efectos civiles. Tenemos ya establecido, si no teórica, al menos prácticamente, la separación entre el sacramento i el contrato, i abierta la puerta para introducir mañana los matrimonios civiles i las más detestables novedades [Destacados míos]... i para esta

8 "Representación que hacen a la honorable cámara de Senadores el señor Arzobispo de la metrópoli de Santiago e ilustrísimos señores obispos sufragáneos de La Serena y Concepción, Santiago 24 de septiembre de 1856", en Obras Cientificas i Literarias del Ilmo. Y Rmo. Sr. Don Rafael Valentín Valdivieso, op. cit. Tomo II, pág. 28. El documento se encuentra en pp. 27-58. 
innovación ¿qué ventaja moral, qué interés político, qué razón siquiera plausible se alega? Yo no be oido una sola.

Este es puro lujo de poder abusivo, rasgo funesto de omnipotencia legislativa"'.

En la "Representación" se hace mención a lo dispuesto por los artículos 103,123 y 168 del Código y lo consagrado por la Iglesia tanto en el Concilio de Trento como en la Constitución Apostólica de Pío VI, de 28 de agosto de 1794 , sobre los impedimentos del matrimonio, y concluir cómo las corrientes ajenas a la Iglesia han intentado en el último siglo "borrar hasta los vestigios de la religión en este vínculo".

Un segundo tema apuntó a lo recogido en el artículo 126 del Código respecto a que la autoridad eclesiástica no permitiese el matrimonio de un viudo si no presentaba "certificado auténtico del nombramiento de curador especial para sus hijos" o la información que acreditare "de que carece de hijos que están bajo su patria potestad o bajo su tutela o curaduría".

Materia que fue abordada desde la perspectiva eclesiástica como un inconveniente y que no consideraba la situación económica de los eventuales afectados, principalmente de los pobres. Así se lo hace saber al obispo Hipólito Salas:

"Con respecto a los pobres, es un gravamen insoportable, sin objeto, que dará lugar a que se perpetúen escandalosos amancebamientos. Un pobre no tiene con qué pagar las diligencias del discernimiento del cargo de curador, ni puede encontrar persona que acepte este cargo, ni muchas veces puede ir siquiera adonde reside el juez de primera instancia que talvez dista de su domicilio treinta o cuarenta leguas... En esta parte la lei se resiente del sistema especulativo que distingue a nuestros legisladores, los cuales, regularmente, acomodan sus leyes a Santiago $i$ Valparaíso $i$ se olvidan de lo que es Chile"lo.

En la "Representación" se hace uso de esta argumentación económica, gastos y viajes, omitiéndose el último párrafo; agregándose que lo exigido al pobre por el viaje en los curatos de campos y las diligencias judiciales este, para poder cumplir lo señalado, debería suspender su trabajo por el cual subsistía diariamente.

Un tercer tema vinculaba los artículos 428, 438 y 508 del Código con la calidad de los tutores o curadores. El punto de fricción con la normativa civil era que contemplaba el arbitrio de ser elegido tutor de pupilos católicos una persona que no profesare la religión católica. 
La "Representación", después de examinar tal posibilidad con el consentimiento de los parientes de los pupilos, hacía notar:

"El cuidado de esta parte ha sido confiado por Dios a los Pastores de la Iglesia, i la lei no puede hacer ilusorio este derecho sagrado, confiriendo a otros la facultad de poder consentir en que se arrebate al rebaño católico el pupilo que fue recibido en su seno"11.

Una cuarta observación derivaba de lo establecido tanto por el artículo 586 que las cosas consagradas al culto divino se regían por el derecho canónico como por el artículo 587 que señalaba que el uso y goce de las capillas y cementerios localizados en posesiones de particulares pertenecían a los dueños de dichas posesiones. El punto de discordia estribaba en la presencia en los lugares indicados -principalmente capillas- de vasos sagrados y objetos pertenecientes al culto, lo cual contravenía lo dispuesto por el derecho eclesiástico de considerar criminal el dar uso profano a lo sagrado. Era lo que hizo notar el arzobispo de Santiago al obispo de Concepción.

En la "Representación" se entrecruza la apelación a los graves disturbios a la religión procedentes de los revolucionarios del momento y las posibilidades de profanación de los objetos sacros por gentes alejadas del catolicismo:

"Como las expoliaciones sacrílegas inferidas a la Santa Iglesia en nombre $i$ bajo el patrocinio de la lei, han sido la fuente $i$ origen de los golpes que la boz formidable del comunismo ba descargado sobre la propiedad, los autores del Código, aleccionados por la historia, ban querido, no solamente reconocer del modo más explícito $i$ absoluto el derecho de la Iglesia a adquirir i conservar bienes con qué costear el culto divino, sino de reglar ella misma por sus respectivas leyes su posesión $i$ administración... El artículo 20 dice que debe darse a la palabra el significado legal; i el vocablo uso, aplicado a las iglesias, de que se vale el artículo 587, comprende, según la disposición del Título X, Libro II, el derecho de habitar en ellas, o de encerrar animales en los cementerios, de cubrir la mesa con los manteles del altar $i$ beber en los cálices $i$ copones. Estamos ciertos de que la idea de estas profanaciones irritará el sentimiento católico de los señores Senadores $i$ más, la generalidad vaga con que se expresa el artículo 587 pueda dar lugar a tales aplicaciones"12.

Un quinto asunto apuntó a la prerrogativa que tendría el Presidente de la República en determinar el establecimiento jurídico de una obra

11 Ibid. p. 36.

12 Ibid. pp. 37-38. 
de beneficencia. En la "Representación" se hizo presente la diferente apreciación entre los artículos 586 y el 2.047 del Código sobre este asunto.

Una sexta cuestión derivó de lo estipulado en los artículos 546, 548 y 559 del Código y que fueron estimados como trabas para el establecimiento de obras de beneficencia y de piedad religiosa, "sugeridas por las máximas de abierta hostilidad contra la Iglesia, que llegaron a surgir en otros países i tiempos de ingrata memoria", le escribe el metropolitano al prelado de Concepción.

Fue uno de los tópicos más resistidos por la Iglesia. En su comunicación, Valentín Valdivieso, se explayó sobre el asunto, haciendo notar las consecuencias de esta clase de disposición en el pasado y en el futuro. Le comentó a Hipólito Salas:

"De lo dicho se infiere que no se puede establecer una Cofradía, casa de ejercicio, seminario... sin la licencia del Presidente de la República. Ud. ve, mi amigo, que reconociendo a la Iglesia su derecho a adquirir libremente bienes de todo jénero i administrarlos según sus cánones, queda después casi todos estos derechos i prerrogativas a merced de los caprichos $i$ malquerencia de los gobernantes. Si a la hostilidad de la lei se añade la que generalmente desplegan (sic) los jueces que deben aplicarla cuando se trata de corporaciones religiosas, ya se dejan ver los terribles golpes que les amenazan. ¿Hai razones que justifican la introducción de tal ominosas trabas? Yo no las diviso... Lo que observo es que, atendida la buena disposición de nuestros compatriotas, son rarísimas las fundaciones que se establecen, que muchos se retraen de este pensamiento por temor a la intervención del Gobierno, cuyo poder tanto $i$ de un modo tan gravoso ensancha boy el Código. Pero, si no hai razones que justifique las medidas que se ban tomado contra las personas jurídicas, sí las encuentro mui poderosas para atacar esas medidas. Creo que se oponen a la Constitución, porque la parte $5^{a}$ del artículo 12 asegura la inviolabilidad de todas las propiedades, sin distinción de las que pertenecen a particulares o comunidades $i$ sin que nadie pueda ser privado de las de su dominio ni de una parte de ella por pequeña que sea, o del derecho que a ella tuviere, sino en virtud de sentencia judicial [Destacados míos]...Si los derechos son anteriores $i$ superiores a la lei, esta no puede trabárselos. Las trabas puestas a las corporaciones $i$ fundaciones de beneficencia, chocan también con nuestros antiguos hábitos de amplia libertad para fundar establecimientos dotados de bienes $i$ promover con ellas la gloria de Dios $i$ el bien del prójimo $i$ estos hábitos han sido tan inherentes a nuestro carácter que aun en tiempo del gobierno colonial resistieron a las limitaciones i cortapisas que imponía la Legislación de Indias, limitaciones que jamás se observaron en Chile. Contrariado este instinto de saludable libertad 
por las disposiciones del Código, es de temer que corte el vuelo al espíritu benéfico que felizmente se desarrolló, o al menos, la experiencia de lo pasado justifica este temor"13.

Fue la materia más tratada y debatida en las epístolas como de igual modo en la "Representación". En este último texto, se reparó que sin la existencia de estas obras los más afectados serían los pobres, los desvalidos:

"Todos aquellos que sufren por su miseria, son una carga pesada para la sociedad, un objeto de distinguida predilección para el cristiano. Su socorro $i$ alivio, al paso que constituye una virtud favorita del cristianismo, es de la más alta conveniencia social... Por esto, las fundaciones i corporaciones de beneficencia merece una protección decidida de las leyes, i si bien el Código contiene saludables disposiciones sobre esta materia, hai algunas que, en nuestra opinión, puede dañar a lo mismo que los legisladores querían favorecer"14.

Una séptima materia, derivó de la anterior, y trató sobre las limitaciones impuestas a la Iglesia para establecer fundaciones, como se desprendía del artículo 547.

Para el arzobispo de Santiago, llamaba la atención la lectura del Código y su Título XXXVIII Libro IV al compararlo con el Título XXXIII Libro I, sobre este asunto. A su juicio,

"En una palabra, la lei favorece a la libertad individual para enriquecerse, $i$ la restringe a mas no poder para desprenderse de las riquezas en beneficio del público. Por cierto que no concibo la razón fundamental de esta disposición que, confieso a Ud., francamente, harto me choca"15.

En la "Representación" se manifiesta claramente que la Iglesia la conforman todas las fundaciones y corporaciones que han surgido de su seno y se rigen por las leyes canónicas.

Un octavo asunto giró en torno a lo establecido en el artículo 965 del Código. Apuntaba a la nulidad del confesor respecto a cofradías puestas a su nombre proveniente de la confesión a un difunto desde dos años atrás. Se trataba de impedir el "abuso" del confesor en cuanto a violar la voluntad del moribundo para que lo beneficiara. Para monseñor Valentín Valdivieso, nadie había estimado hasta 1771 que "era un mal digno de

13 Ibid. pp. 13-17.

14 Ibid. pp. 39-40. El asunto está tratado entre las páginas 39-45.

$15 \quad$ Ibid. p. 17. 
remedio" el señalado abuso, pero la legislación hispana anulaba los legados hechos en la última enfermedad al confesor, tanto a sus conventos, su iglesia y a sus parientes. Lo dispuesto por la normativa civil nacional excedía las prevenciones, le escribía al obispo de Concepción.

En la "Representación" se indica:

"No creemos que la sociedad tenga interés en añadir penalidades $i$ angustias al sacrificio que la religión inspira i consigna en la renuncia del siglo, ni que baya razón para que la sociedad sea mas exigente que Dios mismo en el voto que se le hace, $i$ juzgamos que hai una verdadera conveniencia social en que un padre o una madre tiernos no mueran con el desconsuelo de abandonar sin recursos a la bija que seguramente será la que más se empeña en pedir a Dios por el eterno descanso de sus padres"16.

La novena observación se centró en la disposición del artículo 1056 del Código que otorgaba al Presidente de la República la facultad de designar el establecimiento de beneficencia que sería favorecido por una herencia, que el testador dejaba a su alma.

El cuestionamiento llevado a cabo lo dejó meridianamente puntualizado el arzobispo de Santiago, en su misiva a su hermano de Concepción:

"Esta disposición, en cierto modo, se opone al Capítulo VIII de la sesión XXII del Tridentino, que establece a los obispos ejecutores de la última voluntad en orden a causas pias, i el concilio es algo más que una simple lei canónica, pues que forma como el derecho público entre la Iglesia $i$ el Estado, en los países donde tan solemnemente fue recibido i mandado a ejecutar por el poder civil, como sucede entre nosotros... No se oye otra cosa que las escuelas son el más importante objeto de beneficencia que puede promoverse, i según el señor Amunátegui, en ella solo debe darse instrucción al Entendimiento, porque es una bobería esto de educación al corazón, como si un pedazo de carne colorada mereciera atención. Tendríamos, pues, que, usándose de la facultad de la lei, podría suceder que el dinero destinado para el alma del testador, se invirtiese en pagar actrices $i$ bailarines, en sostener lupanares... hasta en pagar maestros protestantes que pervierten en lugar de instruir a la juventud católica"17

Un último tema tuvo relación con los artículos 2206 y 2207 del Código que contenían lo concerniente al canon de un censo. Se disponía por el Código que la cuota del canon de un censo no podía exceder del

$16 \quad$ Ibid., p. 47.

17 Ibid., pp. 19-21 
$4 \%$ sobre su capital. Todo lo cual, en la visión eclesial, se trataba de "rebajar al cuatro por ciento los censos que actualmente se reconoce al cinco", le hizo saber el arzobispo metropolitano al obispo de Concepción. La "Representación" siguió igual fundamento.

El día 24 de septiembre de 1856, el arzobispo de Santiago junto con los obispos de La Serena y de Concepción, hicieron la mencionada representación ante el Senado, solicitando la modificación de los artículos que hemos examinado ${ }^{18}$. Sin embargo, por elevarse el citado informe fuera del tiempo estipulado, no fue acogido. Y en ello no pudo leerse ninguna predisposición contra la Iglesia; el informe evacuado por la Corte de Apelaciones de La Serena de 22 de octubre de 1855 no fue tomado en cuenta por la Comisión, por haber sido recibido cuando el proyecto del Código Civil de 1855 estaba en prensa ${ }^{19}$.

Con todo, la actitud de la Iglesia puede estimarse de divulgación de este hecho jurídico-político, a través de La Revista Católica, que difundió algunos artículos previamente a la vigencia de este, como fue, v. gr., el decreto de la Intendencia de Santiago, de 13 de diciembre de 1856, respecto a las obligaciones para las edificaciones (Artículos 599-601). El más significativo de este periodo fue lo consignado en su edición del 7 de marzo de 1857, número 486, donde dio cuenta de un comunicado del Arzobispado de Santiago, sobre la entrada en vigencia del Código Civil. Causa extrañeza que este documento de la autoridad eclesiástica, de 1 de enero de 1857, se publicase en tal fecha, máxime cuando lo que apuntaba a difundir eran los artículos respecto del matrimonio que consagraba el nuevo texto legal:

"El primero del corriente ha comenzado a rejir el Nuevo Código Civil, i conviniendo que los párrocos conozcan algunas de sus disposiciones, bemos creído conveniente transcribir a U. los artículos siguientes".

Y a continuación citaba los artículos 98, 105, 106-113, 118, $124-129^{20}$.

18 Últimamente, Carlos Salinas Araneda, ha estudiado la evolución histórico-jurídica de las herencias a favor del alma que se recogió en el artículo 1056 del Código Civil. Cf. SALINAS ARANeda, Carlos: "La influencia del Derecho Canónico en la configuración de las herencias a favor del alma en el Derecho Chileno", en Cattan Atala, Angela-Guzmán Brito (editores), Homenaje a los profesores Alamiro de Ávila Martel, Benjamín Cid Quiroz, Hugo Hanisch Espindola. Ediciones Universidad del Desarrollo, Santiago, 2005, 335-372. También, Salinas ARANeda, Carlos: "Vigencia del derecho indiano en Chile republicano: la personalidad jurídica de las congregaciones religiosas", Revista de Estudios Histórico-Jurídicos, Universidad Católica de Valparaíso, año 2000, vol. XXII, 299-316.

19 Cf. Alejandro GuzMAn BRITO, Andrés Bello codificador. Historia de la fijación y codificación del derecho civil en Chile Ediciones de la Universidad de Chile, Santiago, 1974, Tomo I, 377.

20 "Arzobispado de Santiago, enero 1 de 1857", La Revista Católica, Santiago, 7 de marzo de 1857. 
Aun así, la Iglesia, a través de su medio de prensa, manifestó la autonomía que poseía en determinados ámbitos, como ser el educacio$\mathrm{nal}^{21}$.

Consignemos que la prosecución del proceso de codificación nacional significó, nuevamente, que la Iglesia hiciera sentir su voz cuando consideró que se afectaba la jurisdicción eclesiástica. Esto sucedió al plantearse el proyecto de Código Penal. En esa oportunidad su reclamo de 1873 fue acogido sustancialmente, al suprimirse los artículos 118, 261 y 262 de dicho proyecto 22 .

Posteriormente, al generarse el Proyecto de ley de Organización y atribuciones de los Tribunales, ese mismo año de 1873, los prelados nacionales hicieron ver al Papa su preocupación por las intenciones gubernamentales para que los tribunales civiles tuvieran competencia en las causas temporales de los eclesiásticos ${ }^{23}$.

21 Véase, a título de muestrario, las aseveraciones: "En Chile los cánones del Concilio de Trento son leyes nacionales. Aunque no lo fueran por la expresa y solemne sanción que recibieron, son obligatorios desde que la Constitución declara al catolicismo la única y exclusiva religión de la República, cuyas instituciones y doctrinas se obligan por juramento a defender y proteger los altos poderes del Estado. Los gobiernos republicanos de Chile han sido fieles a estos católicos y liberales principios, y desde el restablecimiento del Seminario de Santiago en 1836 supieron romper con las mezquinas tradiciones de la monarquía, renunciando a las tendencias centralizadoras de la legislación española. Tanto el Supremo Gobierno como la Universidad han respetado siempre la provechosa libertad que deben tener los Seminarios para ser regidos por la autoridad que mejor puede consultar sus intereses. Y siempre que se ha tratado de planes de estudio, métodos de enseñanza, adopción de textos, etc., se ha prescindido de nuestro Seminario". Cf. "Estudios del Seminario de Santiago", La Revista Católica, Santiago, 7 de marzo de 1857; "Cuando en otra época se discutió en el Congreso este proyecto, combatimos el arcículo sétimo que impone a los monasterios la carga de sostener una escuela elemental o superior, según lo tenga a bien el P. de la República, atendidas sus rentas. En 1850 el señor Montt sostenía como Diputado la justicia de ese artículo i aducía las razones que a su juicio la demostraban: nosotros las combatimos en nuestros números 210 i 211: al presente reproducimos nuestros artículos con la esperanza de que los legisladores tributando un homenaje de respeto a los principios de la justicia, no impongan a un reducido número de personas una carga más pesada que a los demás. A la verdad, los monasterios no viven a espensas del Estado; pagan sus contribuciones como los particulares". Cf. "Proyecto de lei sobre instrucción primaria", La Revista Católica, Santiago, 31 de octubre de 1857.

Manuel Montt había presentado en la sesión de la Cámara de Diputados de 15 de octubre de 1849 , su proyecto de ley mencionado, tomando como base el informe de Domingo Faustino Sarmiento de su viaje a los EE.UU. y modificado por Miguel de la Barra y Antonio Varas. Cf. "Proyecto de lei sobre instrucción primaria presentado por don Manuel Montt", en Discursos Papeles de Gobierno y Correspondencia de D. Manuel Montt, reunidos y anotados por Luis Montt, Santiago, 1982, Tomo I, 256-280.

22 "Reclamación sobre el Proyecto de Código Penal", Santiago, 11 de noviembre de 1873, firmado por Rafael Valentín, arzobispo de Santiago, José Hipólito, Obispo de Concepción, y J. Francisco de Paula, Obispo de Ancud, en Retamal Fuentes, Fernando (n. 3) Volumen I/Tomo III, pp. 1287-1294.

23 "Proyecto de ley de Organización y atribuciones de los Tribunales". Carta del Episcopado de Chile al Romano Pontífice, Santiago de Chile, 20 de octubre de 1874; "Instrucción Apostólica", Roma, 4 de marzo de 1875; "Presentación de los Obispos chilenos al Senado 


\section{La lectura del Código Civil desde la Teología Moral, COMO EXPRESIÓN DE LA CONCORDANCIA ENTRE LA LEY CIVIL Y LOS PRECEPTOS ECLESIÁSTICOS}

Para examinar las materias del Código Civil, la Iglesia contaba con una disciplina que desde el siglo XVII estaba encaminada a determinar la concordancia entre lo prescrito por ella y los asuntos ventilados en la sociedad civil: la Teología Moral.

Cabe indicar, brevemente, que desde la obra de San Alfonso María Ligorio (1696-1787), la Teología Moral quedó firmemente consolidada como Moral casuística.

Para determinados autores, la Teología Moral se separó de la Dogmática pero quedó bajo la fuerte influencia del Derecho Canónico, donde se privilegió la ley con menoscabo de la conciencia ${ }^{24}$. La Theología Moralis de San Alfonso, con que se conoció a partir de la edición de 1757 su primitiva Medulla Theologiae Moralis R.P. Hermanni Busembaum S.I. cum adnotationibus per R.P.D. Alphonsum di Ligorio aparecida en 1748, junto a la obra de J.P. Gury, Compendium Theologiae Moralis, publicada en 1850 , sirvieron de orientación en nuestro país para estudiar el contenido del Código Civil.

La Teología Moral conforma, entonces, "aquella parte de la teología sobrenatural [la que tiene por fundamento la divina revelación] que trata de los actos humanos en cuanto son medios para conseguir el fin último sobrenatural. Puede también definirse: "La ciencia que, apoyándose en los principios revelados, trata de las leyes y de los medios

de la República", Santiago, 8 de junio de 1875, en Retamal Fuentes, Fernando (n. 3) Volumen I/Tomo III, 1348-1370.

Con anterioridad, en 1864, los dos prelados, el de Santiago y el de Concepción, hicieron llegar al ministro de Justicia sus observaciones sobre otro proyecto similar. Cf. SALAS, José Hipólito, Comunicación dirigida al señor Ministro de Justicia por el mui Reverendo Arzobispo de Santiago i el reverendo Obispo de Concepción sobre el Proyecto de lei de organización i atribuciones de los Tribunales. Imprenta Nacional, 1864.

Cf. Fernández, Aurelio: Compendio de Teología Moral, Madrid, 1999 (22 Ed.), 36. También, Caffara, C.: "Historia de la Teología Moral", en Rossi-Ambrogio Valsecchi, Leandro (dirigida), Diccionario enciclopédico de Teología Moral, Ediciones Paulinas, Madrid, 1980 , pp. 436-454. Un moralista contemporáneo ha precisado que la autonomía de esta Teología Moral (imbuida en la Moral casuística) exhibía las siguientes deficiencias: a) Separación de los principios teológicos; b) Excesivo legalismo (importancia otorgada a la "obligación", al deber; y la significación de la ley positiva, eclesiástica, que provocó la "juridización" de la moral); c) Positivismo teológico y pragmatismo moral ( privilegiar el argumento de autoridad); d) desvinculación de la filosofía (no vive el tiempo de ella y las ideologías) y e) Vinculación excesiva con la praxis penitencial. Cf. VIDaL, Marciano: Moral de actitudes, P.S. Editorial Madrid, 1975, Tomo I. Moral Fundamental, pp. 35-43. 
según los cuales el hombre debe dirigir sus acciones a la consecución del último fin" 25 .

Al entrar en vigencia el Código Civil un grupo de autores eclesiásticos emprendió la tarea de confrontar el nuevo cuerpo legal con los principios teológicos morales.

El impulso dado por el arzobispo Valdivieso a los estudios teológicos y su apoyo al Seminario de Santiago favoreció grandemente la labor indicada. Precisemos que desde 1853 se impartía la teología dogmática y la moral, el derecho canónico y la historia eclesiástica. A esta preparación académica, reconocida en el ambiente intelectual de la época, se sumó una nueva construcción, comenzada hacia fines de 1854 , con que se vio favorecido el Seminario ${ }^{26}$.

De esta manera, es muy posible que, en cuanto se promulgó el Código Civil, los profesores del ramo de Teología Moral del Seminario acometieran la tarea de cotejar los principios canónicos-teológicos con los contenidos en la ley civil. Y, más tarde, hayan estimado necesaria la divulgación impresa de aquellas enseñanzas.

En 1864 el Presbítero Lorenzo Robles (1817-1902) publicó su Concordancia de la Teolojía Moral con el Código Civil Chileno en los tratados de Justicia i de Derecho i Contratos $^{27}$. Fue el primer intento claro de sistematizar la posición de la Iglesia con algunos tópicos que fueron considerados controversiales.

Posteriormente, su autor, que impartía esta asignatura en Santiago, acotó, en su segunda edición, de 1896, la conveniencia de reducir las múltiples referencias a las leyes civiles de su anterior texto y poner de relieve, "las disposiciones más importantes de nuestro Código que necesita saber en el ejercicio de su ministerio un sacerdote ilustrado, haciendo notar principalmente los puntos en discordancia con las enseñanzas

25 Ferreres, Juan B., S.I,: Compendio de Teología Moral, Imp. Eugenio Subirana, Barcelona, 1923 ( $2^{a}$ Ed.), Tomo I, 3. La Teología Moral se divide en Fundamental y Especial. En la primera se estudian los principios más generales de los actos humanos, las leyes que regulan las acciones, la conciencia por medio de la cual se aplican subjetivamente las leyes, de los pecados y de las virtudes en general; en la segunda, las cosas particulares, de las virtudes, de los preceptos de Dios y de la Iglesia y los sacramentos.

El sacerdote jesuita mencionado publicó en 1920 una obra general sobre la cuestión central de este apartado. Cf. Ferreres, Juan B S.I: La justicia, el derecho y los contratos conforme a los principios de la moral católica ya los Códigos Civiles de España, Portugal y de las diversas naciones de la América Latina. Imp. Eugenio Subirana, Barcelona, 1920.

26 Se ha indicado que para el periodo 1840-1880 la actividad teológica chilena desarrolló varias temáticas: a) la libertad de la Iglesia, b) la oposición al Romanticismo filosófico y teológico, c) una revalorización de la escolástica, por influencia de la teología moderna francesa, d) una atención por el Milenarismo de M. Lacunza, e) una reacción teológico-social ante las ideas liberales y socialistas. Cf. Salinas Campos, Maximiliano: "Notas varias sobre actividad teológica chilena entre 1840 y 1880", en ArTEAGA Ll., José (dir) (n.5) pp. 12-37.

27 La obra, de 337 páginas, fue impresa por la Imprenta Nacional de Santiago, en 1864. 
de la Teolojía, i sin que se deje de tratar en él todas las materias que abraza nuestro Código que tienen relación con la doctrina eclesiástica y con la conciencia"28.

En 1871, la Imprenta del Correo, sita en Santiago, publicó la obra Tratado Teológico-legal de la Justicia, o sea concordancia del derecho chileno con la Teolojía Moral en materia de Justicia, cuyo autor era el presbítero Zoilo Villalón Aránguiz (1823-1881). El citado sacerdote se había desenvuelto durante el decenio de 1850 como secretario del arzobispo de Santiago, D. Rafael Valentín Valdivieso. Estudió Leyes y recibido de Abogado en 1862 ingresó a la Compañía de Jesús.

En la ciudad de Concepción, en 1896, el presbítero Eliodoro Villafuerte dio a la publicidad su Tratado Teológico de la Justicia y el Derecho en concordancia con el derecho Chileno tomado de la Teología Moral del P. Gury ${ }^{29}$. La importancia de difundir tales conceptos fue valorada por el Excmo. Monseñor José Machi, Delegado Apostólico en Lima, en carta a su autor: "Después de los Catecismos Dogmáticos y de las Teologías Populares, que tan buenos frutos están dando, faltaba popularizar la Teología moral, y Ud. ha tenido el acierto de llenar ese vacío"30.

28 Compendio de la Concordancia de la Teolojía Moral con el Código Civil Chileno en los tratados de Justicia, Derecho i Contratos por el Presb. Lorenzo Robles. Memoria única aprobada por la Facultad de Teolojía de la misma Universidad, con ocasión del Certamen Literario del año de mil ochocientos sesenta i tres. Segunda Edición con algunas importantes modificaciones. Imprenta San Diego, Santiago, 1896, "Advertencia".

29 El año anterior, el presbítero Villafuerte, de origen ecuatoriano, había demostrado su familiaridad con la obra del P. Gury, al dar a las prensas su volumen, El cristiano de conciencia ilustrada. Compendio de principios morales tomados de la Teología Moral del P.J.P. Gury, Imprenta Barcelona, Santiago, 1895, de 458 páginas.

30 Carta del Excmo. Sr. Delegado Apostólico Monseñor Machi, Lima, enero 8 de 1896, al Presbítero Sr. D. Eliodoro Villafuerte, en Tratado Teológico de la Justicia y el Derecho en concordancia con el Derecho Chileno tomado de la Teología Moral del P. Gury por el Presbítero Eliodoro Villafuerte. Imprenta Española del Comercio, Concepción, 1896, pp. IV-V. A esta altura, cuando se había promulgado el paquete de las llamadas comúnmente, "leyes laicas", en 1884, en el uso de los Catecismos se introdujo una inflexión notable: además de instrumento de propagación del conocimiento de los preceptos eclesiásticos se agregó el de la formación política del clero y laicado católico. El Licenciado en Teología y Dean de la Iglesia catedral de Concepción, Domingo Benigno CRuz, publicó El Clero y la Política o la participación del clero en la política. Memoria premiada por la Universidad de Chile, Barcelona, 1889, donde sostuvo: “¿cuál puede ser esa autoridad religiosa que presente a los individuos y a las naciones un código completo y perfecto de verdades religiosas y morales que puedan ser el ancho cimiento en que descanse la sociabilidad humana?... Es evidente que solo la Iglesia católica presenta esa firmísima base á las sociedades humanas. Pero la Iglesia guía á los individuos y á los pueblos por medio de sus Pastores, por su parte docente, es decir, por medio de los Obispos que dirigen á sus sacerdotes, estando todos ellos sometidos al Papa. El clero católico es, pues, el llamado por el interés mismo de la sociedad civil á intervenir en su formación y en su administración, ò sea a tomar participación en la alta política, en las leyes y costumbre de los pueblos. Queda, pues, demostrado que la naturaleza misma de la sociedad exige la participación del clero en la política". Cf. Cruz, Domingo Benigno, op. cit. p. 71. 
De los tres textos, nos serviremos del P. Lorenzo Robles con mayor detenimiento, por la proximidad de su obra con la repercusión del Código Civil. La obra del P. Villafuerte se hizo eco de las otras incidencias, las denominadas "Leyes Laicas", por lo cual se desvió el impacto a otras materias. La del P. Villalón, si bien es la más rigurosa en su tratamiento, se hizo cargo, además, de la recepción del Código de Comercio.

Empero, seguiremos un orden cronológico para dar cuenta de las obras mencionadas.

El texto del Pbro. Robles va a constituir un ejercicio que va a contraponer las exigencias de la doctrina católica con los imperativos emanados de la ley civil. La estructura de su obra revela una exposición inicial del contenido, seguido de los principios teológicos atingentes y finalmente la referencia a lo prescrito por el Código Civil. La obra del P. Robles desplegó las siguientes materias:

\section{Parte Primera}

De las nociones jenerales de la justicia i del derecho i su división. Definición de la lei, discordancia del derecho canónico con el civil.

Esta primera parte comprendía siete puntos que se extendían desde las principales especies de derecho, objeto i sujeto del dominio hasta las servidumbres.

\section{Parte Segunda}

Nociones sobre los modos de adquirir.

Abarcaba cuatro capítulos que trataban desde de la ocupación i sus especies hasta las nociones jenerales sobre las prescripciones adquisitiva i liberativa.

\section{De los Contratos.}

Fue el título más extensamente examinado. Dividido en dos partes, la primera "Nociones sobre los contratos, cosas esenciales, naturales i accidentales de todo contrato", comprendió cuatro capítulos que dieron cuenta desde "De las cosas que se requieren para contratar" hasta "De las obligaciones que no nacen de convención espresa, sino de la voluntad presunta de las partes"; una segunda parte, "De los contratos en especie", estaba estructurada en base a dos secciones, siendo la primera integrada por seis capítulos, que contenían desde el tratamiento de la compraventa hasta la prenda, hipoteca i transacción; una segunda sección, con tres capítulos, centrados desde el mutuo i la usura hasta los contratos aleatorios.

\section{Tratado de la Restitución.}

Dividido en dos partes: la primera, "De la violación del derecho, o sea de la injuria", estaba explicado en dos capítulos; la segunda, "De la 
restitución", dividida a la vez en dos secciones, la I "De la restitución en general" con cinco capítulos, donde se exponían desde la obligación de restituir hasta las causas que excusan de la restitución, y la II "De la restitución en especie" desplegado en tres capítulos.

Finalmente incorporaba un Capítulo Unico, "Del matrimonio", exponiendo brevemente las nociones jenerales, dado que a la fecha se había promulgado la ley del matrimonio civil.

Como se puede apreciar, el volumen del Pbro. Robles revisaba determinadas materias del Código Civil, siendo los Libros I, II y IV los que demandaron su mayor atención y, en menor medida, el Libro III.

Espigaremos del volumen en comento los asuntos que pusieron de manifiesto los matices diferenciales entre el Código Civil y lo que reservaba para tales cuestiones no solo la ley canónica sino la doctrina teológica.

Una diferencia fundamental, entre la perspectiva secular y la eclesiástica, fue lo referido a determinados conceptos o nociones, donde la contraposición estribó entre lo que constituía lo esencial de la forma.

Valga de ejemplo de la diferencia entre ambos referentes, la siguiente puntualización:

"Lei, según nuestro Código Civil "es una declaración de la voluntad soberana, que, manifestado en la forma prescrita por la Constitución manda, probibe o permite".

Según el derecho canónico, conforme con el derecho natural-Lei, es la ordenación estable del superior impuesta para el bien común de la sociedad.

De estas definiciones se deduce que el Código ha definido la manera como se hace la lei i el objeto de ella, pero no la lei según su esencia, que es atender al bien común de la sociedad; pues bien puede suceder que la voluntad soberana, aunque se manifieste en la forma que prescribe la constitución, sancione una disposición injusta ante la lei canónica i natural, i aun contra la moral i las buenas costumbres, casos en que no habría obligación de obedecerla, porque no seria lei sino en la forma" [Destacados míos] ${ }^{31}$.

En la materia del "dominio", nuestro autor puntualizaba que si bien "La lei civil permite el ejercicio de un oficio para la vida, la lei

31 Robles, Pbro. Lorenzo (n.29) p. 12. Bernardino Bravo Lira, en 1985, reparó en la diferencia conceptual en torno de la ley, establecido en las Siete Partidas de lo consignado en el Código Civil, que es muy similar a lo sostenido por el Pbro. Robles, entre la esencia y la forma de la ley. Cf. "Vigencia de las Siete Partidas en Chile", en Bravo Lira, Bernardino: Derecho Común y Derecho Propio en el Nuevo Mundo, Editorial Jurídica de Chile, Santiago, 1989, 99-101. 
eclesiástica prohibe todo oficio i profesion en que hai peligro probable de perder la vida"32.

En cuanto a la materia del dominio de la Iglesia:

"Nuestro Código Civil como la constitución Estado recoce (sic) (reconoce) en la Iglesia el pleno derecho para adquirir bienes temporales, desde que el Tridentino (Concilio de Trento\} es una lei del estado, i nuestro Código deja la libertad de rejirse en órden a la adquisición de dominio per (sic) (por) el derecho canónico, tanto a la Iglesia en general, como a las corporaciones que vive bajo su dependencia i jurisdicción" 33 .

Empero el Código Civil restringía esta capacidad del religioso para recibir herencia o legados; ante esto, el Pbro. Robles hacía notar que en la práctica se observaba "la lei civil, porque sería ineficaz la doctrina de la lei canónica" y ponía la instancia de la conciencia individual como única directriz ante el dilema:

"Cuando la lei civil está en oposición con la lei canónica, aquella no obliga en conciencia, $i$ por otra parte que la lei civil legislando en materias de su resorte obliga a veces también en conciencia. A lo que debemos agregar que muchas veces el Derecho canónico ba arreglado sus disposiciones en conformidad a las leyes civiles vijentes" 34 .

Respecto a la patria potestad había confluencia tanto del derecho natural y la ley civil sobre los efectos de esta respecto a las obligaciones de los padres con relación a sus hijos. Importa destacar el papel asignado a la mujer por la Teología Moral. Este era más significativo en la esfera del dominio que lo que consagraba el Código Civil. Podía disponer de los denominados bienes sociales para satisfacer las necesidades de su familia "cuando el marido no quiere llenarlas" - "No peca la mujer que sustrae ocultamente algo para satisfacer las necesidades de la familia"- o llevar a cabo acciones benéficas, limosnas, de acuerdo "a las costumbres de las mujeres del lugar i de su condición". La argumentación doctrinal teológica, en base de San Alfonso de Ligorio, era:

"La razón es porque ella es señora i no esclava; i aunque la lei civil no le dé un dominio activo sobre aquellos bienes, no le desconoce un cierto derecho que tiene a ellos. Además, esto no es un inconveniente para presumir la voluntad del marido, con tal que use del derecho como lo bacen otras

\footnotetext{
32 Robles, Pbro. Lorenzo, (n. 29) p. 18.

33 Ibid. pág. 21.

34 Ibid, 26 ,
} 
mujeres de su condición; $i$ dado caso que aquel manifestase repugnancia, ella podría hacerlo ocultamente, porque su discenso seria irracional" 35 .

En cuanto a los legados para causas pías, "que constan por testamento nulo, valen en el fuero de la conciencia, porque desde que ha sido declarada la voluntad del testador, quedó bajo la jurisdicción de la Iglesia, la cual admite los legados a favor de la religión, prescindiendo de las formalidades esternas de los testamentos"36.

También había matices en cuanto a la buena fe. De acuerdo, al Pbro. Robles:

"A la buena fé se opone el error, el dolo $i$ el fraude. En conciencia, generalmente hablando, el error no es contrario a la mala fe', pero como la lei civil no irá directamente a la conciencia en este caso, sino a lo que comúnmente sucede; presume la mala fe sin que admita prueba en contrario en el error de derecho, $i$ admite la buena fé cuando el error es de becho. Decimos que en conciencia no se opone el error a la buena fe, porque es mui fácil concebir que una persona que posea tenga firme persuación (sic) de que la cosa que posee $i$ adquiere es lejítima, ocultándosele el vicio de ella por ignorancia u otro motivo. Sin embargo, en uno i otro derecho es un principio reconocido que la mala fé comienza desde el momento que se conoce ser ajena la cosa, si se exceptúan ciertos casos que luego veremos. Además, también es cierto que la buena fé siempre se presume, i la mala fé debe probarse" 37 .

En cuanto a la causa de los contratọs, que el Código Civil desarrollaba desde los artículos 1467 al 1469, se advertía el parecer teológico respecto a la obligación en conciencia, establecido del modo siguiente:

"O no se ha puesto la obra por la cual se da el precio o se ba puesto; en el primer caso es enteramente nulo el contrato i no hai obligación de cumplirlo; en el segundo caso, es decir, si se puso la obra, la sentencia más común dice que se puede recibir i retener el precio, i que aun se debe de justicia" 38 .

Respecto a la compraventa, la insistencia fue puesta en el justo precio. Bajo el expresivo rótulo La conciencia $i$ la lei en orden a la licitud del precio, el Pbro. Robles afirmaba:

Ibid. pp. 39-40.

Ibid. p. 86. Lo mismo ocurría con los ejecutores testamentarios o albaceas, donde la doctrina teológica y el Código coincidían en cuanto a la duración del albaceazgo y el cumplimiento de los legados a favor de las obras pías (Ibid. 109) Supra nota 20.

37 Robles, Pbro. Lorenzo (N. 29) p. 116.

38 Ibid. $137-138$. 
"No es lo mismo la justicia del precio ante la lei civil o en el foro esterno que ante la conciencia. Aquella da acción contra el vendedor o comprador solamente por lesión enorme que tiene lugar cuando el precio que recibe el vendedor es inferior a la mitad del justo precio de la cosa, o la cosa que recibe el comprador es inferior en valor a la mitad del precio que ha pagado por ella* (* Dar 16 por lo que solo vale 10 seria lesión enorme, o viceversa, recibir 10 en lugar de 16). En conciencia el precio es siempre ilícito cuando se vende una cosa en más del precio justo, o se compra en menos de lo que vale, de suerte que el contrato debe rescindirse, o resarcirse el daño no solo por lesión enorme, sino también siempre que se violen las reglas de la equidad $i$ justicia entre el valor de la cosa $i$ el precio dado.

Distinguen al efecto los teólogos, precio legal i natural o vulgar. Precio legal es el que fija la lei o el magistrado con autorización de ella, v.gr., el del tabaco, naipes, etc.; $i$ vulgar o natural es el que tiene la cosa, atendida la común estimación de los hombres peritos en la materia; el primero es fijo e indivisible, es decir, no admite latitud, a no ser que la lei fuese injusta o estuviese derogada; el segundo sí que la admite según la variedad de los casos... Según esto podemos sentar la siguiente doctrina generalmente enseñada por los teólogos:

1. Las cosas viles $i$ las necesarias admiten siempre menos latitud en el precio que las cosas preciosas $i$ no necesarias...

II. El valor de la cosa no se ha de tomar según su dignidad sino según el uso que tenga en el comercio...

111. Se peca contra justicia conmutativa siempre que se vende algo en más del precio supremo o se compra en menos del precio infimo tprecio supremo, es sobre el cual no puede venderse justamente la cosa; precio infimo, es el que en menos del cual no puede comprarse. Corresponde a la división del precio natural o vulgar)" 39 .

Criterio teológico que orientaba acoger la licitud del monopolio público, dado que era constituido por la autoridad legítima con la finalidad de hacer prosperar el comercio o la industria, y considerar el monopolio privado como ilícito principalmente si se dañaba el bien común o se cometía fraude u engaño para impedir la introducción por otros de nuevas mercaderías; o adquirir todas para venderlas más caras, etc. ${ }^{40}$.

\footnotetext{
39 Ib. $168-169$.

40 Ib. 172-173. El autor incorpora en su argumentación dos realidades: una, la del mundo obrero y artesano, donde la enseñanza de su arte fuese a un precio injusto; la otra, el contrato de venta mohatra, que "consiste en simular la venta de un objeto, comprando una mercadería a crédito i a mui subido precio para revenderla luego al mismo comprador a mui bajo precio i al contado", que condenó el Papa Inocencio XI y la Lei 2, Tit.7 de la Partida 5. Para los teólogos la eventual licitud de este contrato guardaría relación con la no existencia de pacto de retroventa o de cometer usura.
} 
El autor del Compendio al examinar el censo, apostillaba del cambio de sentido que había tenido esta locución y traía a colación la concordancia entre teólogos y juristas respecto a su clasificación. De igual modo, afirmaba que respecto al contrato trino, por ser este un contrato de sociedad que comprende tres contratos (de sociedad, de seguros del capital y de venta del lucro incierto), el parecer de los teólogos era cuestionar su licitud ${ }^{41}$. En cuanto al contrato de mutuo, los principios teológicos obligaban en conciencia otorgarlo a los pobres que:

"piden i tienen esperanzas de restituir, es la razón porque hai obligación estricta de socorrer al prójimo constituido en necesidad; la hai también de prestar a los ricos que bic et nunc necesitan del mutuo, porque el precepto de caridad nos obliga para con todos los hombres i nos exije que prestemos de buena gana, lo que querríamos que en igual caso se nos prestase" 42 .

Una materia tratada extensamente desde la teología moral fue la usura, ilícita y contraria al derecho natural, al divino, al eclesiástico y al unánime consentimiento de los teólogos ${ }^{43}$.

En cuanto a la materia de la donación Inter vivos el Pbro. Robles hacía el siguiente alcance entre la perspectiva teológica y lo normado por el Código:

"La donación Inter vivos aunque sea meramente verbal, con tal que esté revestida de las condiciones necesarias es válida por derecho natural $i$ trasfiere por consiguiente el dominio irrevocablemente. Son condiciones necesarias, para la validez de la donación: 1. capacidad de donar en el donante; $i$ 2. espontaneidad. Respecto de la aceptación en el donatario, la creen muchos de derecho positivo, pero generalmente se admite entre los teólogos que la donación hecha directamente a Dios, es válida sin la aceptación, porque se considera como un voto. Según el derecho positivo las donaciones deben bacerse conforme a las formas prescritas por la lei, al menos para que tengan efecto en el fuero esterno. Los principios que establece el Código Civil, respecto de las donaciones son relativos a la babilidad del donante, a la capacidad del donatario para aceptar i a las formalidades que deben observarse" 4 .

En lo referente al contrato de promesa, nuestro autor reparaba que el Código Civil "nada estatuye con especialidad acerca de este contrato", coincidiendo respecto a la promesa de los esponsales el criterio civil

Ib. 191.

Ib. 196 .

Ib. $200-204$.

Ib. 205 . 
con el canónico-teológico que su cumplimiento recaía en la obligación en conciencia ${ }^{45}$.

En cuanto a la injuria, advertía que:

"vamos a tratar solamente de la injuria en orden a los bienes de fortuna, a saber, del burto $i$ sus especies fque el llamaba "De los pecados contra Justicia"); porque de las otras especies de injurias, es decir, con respecto a los bienes del cuerpo, del honor, o de la fama, pertenecen más bien al quinto precepto del Decálogo" 46 .

Bajo este predicamento señalaba que el hurto "es un pecado mortal" que atenta contra el derecho natural, la caridad y la justicia; y el hurto sacrílego i la rapiña, eran pecados más graves. La duda teológica era la determinación "de la cantidad precisa que constituye pecado mortal... En nuestras conferencias morales se discutió largamente este punto i la mayoría se inclinó a sentar como materia grave para pecado mortal sería dos pesos" 47 .

En cuanto a la obligación de restituir, era notable la convergencia del tratamiento de la buena fe en el Código Civil y lo enunciado por la doctrina teológica. En cuanto a la culpa damnificante, el Compendio distinguía la teológica de la jurídica:

"La culpa teolójica, que se llama así porque se refiere por los teólogos al fuero de la conciencia, es aquella que lleva consigo la ofensa de Dios, esto es, un pecado formal, ya sea grave o leve. Mas, la culpa jurídica es la omisión de la diligencia o cuidado que debemos tener para no dañar al prójimo, i la cual imputa casi siempre el derecho bumano, prescindiendo de pecado"48.

En cuanto a la llamada "cooperación injusta" pasaba revista a las consideraciones teológicas respecto a los nueve modos en que se presentaba la cooperación al daño del prójimo: mandando, aconsejando, consintiendo, adulando, amparando al ladrón, participando del o en hurto, enmudeciendo, no estorbando y no manifestándolo ${ }^{49}$. Y en lo concerniente a las circunstancias de la restitución, la exposición de los principios teológicos respecto de la solidaridad, tanto absoluta como condicional, y las "reglas prácticas acerca de la obligación de la solidaridad", coincidían con las disposiciones civiles sobre el asunto ${ }^{50}$; aun-

\footnotetext{
$45 \quad$ Ib. 210.

46 Ib. 229.

47 Ib. 232.

48 Ib. 244-245.

49 Ib. 247-254

50 Ib. 254-257.
} 
que, como es fácil comprender, las consideraciones teológicas quedaban de manifiesto respecto a la pregunta de si " el deudor esté obligado a restituir en caso de hallarse en la misma necesidad grave o estrema que el acreedor" se planteaba que para resolver aquello:

"Es preciso atender: 1. Si el acreedor se encuentra ya en necesidad grave $i$ el deudor solamente pagando se constituye en ella, 2. Si uno $i$ otro, se encuentran en grave necesidad, $i$ el deudor se ponga en necesidad estrema pagando; i 3. Si uno i otro están en estrema necesidad. Según esto, podemos resolver con la opinión más probable. Si lo primero, debe restituir, si lo segundo, es decir, si uno i otro se ballan en necesidad grave, $i$ restituyendo el deudor cae en la estrema, según Guri siguiendo a Rocanglia $i$ otros, dice que puede diferir la restitución si la deuda no proviene de delito, pero San Ligorio parece inclinarse a la contraria, esto es, que en todo caso se escusa de restituir al deudor en tales circunstancias.

Si lo tercero, es decir, si uno i otro están en necesidad estrema, es más probable que puede omitirse la restitución; porque en este caso todas las cosas se bacen comunes. Así San Ligorio" 51 .

En lo que concernía a la restitución "por el daño causado en los bienes del alma", tanto naturales como sobrenaturales, distinguía que respecto a los segundos, "el que con mentira, fraude o violencia, o por otro medio injusto, indujo a algunos a cometer un pecado mortal, tiene obligación grave de justicia de reparar el daño, ya quitando la fuerza o violencia o manifestando el error"; el mismo procedimiento se aplicaba "acerca del error especulativo sobre los principales artículos de fe". En cuanto a los bienes naturales, "el que privó a otro de la memoria, razón, etc., por medio de veneno u otra bebida artificial, está obligado en justicia, a reparar todo aquello que es posible en el daño que injustamente causó" 52 .

En cuanto a la reparación o restitución en orden a los bienes del cuerpo, a saber, por homicidio, las consideraciones teológicas quedaban contempladas, en gran medida, en el artículo 2314 del Código Civil. En cuanto al estupro, se establecía siguiendo a los citados teólogos, que:

"No bay obligación de restituir por el daño meramente natural, esto es, por la lesión material o pérdida de la virginidad (al menos según la opinión más probable); porque semejante daño no puede compensar con dinero. Tampoco bai obligación de restituir por el daño temporal que se siguió del

\footnotetext{
51 Ib. 270.

52 Ib. 271-272.
} 
estupro, si se exceptúa la educación de la prole, cuando la mujer consintió espontáneamente en ello"53.

Sin embargo, aquel que deshonrara a una doncella con fraude, amenazas o violencias, "está obligado a reparar los daños que causó tanto a ella como a sus padres en el honor i bienes, ya sea dotándola o aumentando la dote, porque él es causa eficaz de todo el daño"54. El Compendio seguía el criterio del texto civil en cuanto a la clasificación de la filiación, acotando que el Código no protegía a la persona engañada con promesa de matrimonio y la única protección que otorgaba era solamente a los hijos.

Y la restitución por adulterio, "las obligaciones de uno i otro adúltero se han de fijar según las circunstancias, atendiendo ya a si el adulterio fue plenamente voluntario por una i otra parte, o dañoso a la familia" 55 .

Respecto a la restitución por daños en los bienes de fortuna, en casos particulares, pasaba revista de los tributos, considerando que las contribuciones fiscales pertenecían a la autoridad suprema y legítima; a los daños inferidos con ocasión de la milicia, había que despejar si eran daños "en una acción de guerra común a todos", donde no existiría, entonces, obligación de nada, o de una guerra "evidentemente injusta" donde debían responder de todos los daños. Y en cuanto al despojo de los bienes eclesiásticos hacía notar que la doctrina teológica sentaba lo siguiente:

"Los gobiernos que quitan los bienes eclesiásticos a las iglesias o corporaciones, con cualquier pretesto que sea, $i$ aunque se obliguen a subvenir a los gastos de las iglesias, o mantenimiento de dichas corporaciones, contra la voluntad de éstas, cometen una verdadera usurpación $i$ rapiña, quedando obligados, como verdaderos ladrones, a la restitución de los daños; lo que tiene lugar aun cuando los ocupen, favoreciéndoles la lei civil; $i$ ni vale prescripción alguna en conciencia por la mala fe con que los poseen, pues que la lei es injusta $i$ abiertamente contraria a la lei canónica $i$ a las mismas constituciones de los diversos Estados que ordinariamente reconocen en las iglesias el derecho de adquirir $i$ mandan respetar la propiedad ajena.

Los particulares no pueden adquirir estos bienes ni aun a título oneroso; $i$ solamente se escusarán de restituir; en caso de haberlos obtenido de manos de tercero $i$ de buena fe; no pudiendo ni aun prescribirlos en conciencia

\footnotetext{
Ib. 274 .

Ibid.

Ib. 277
} 
los primeros que los compraron de mala fe. La prescripción lejítima para estos bienes es de cuarenta años, como se ha dicho" ${ }^{" 56}$.

Con esta materia concluía el grueso de la exposición ${ }^{57}$.

Lo realizado por el P. Zoilo Villalón, Tratado teológico-legal de la Justicia o sea concordancia del derecho chileno con la Teología Moral en materia de Justicia, se ajustaba a un claro propósito:

"Desde que la nueva legislación que rije en Chile, dejando abolida la antigua en las materias que aquella toca, introdujo tan sustanciales $i$ numerosos cambios en los principios que sirven de base a los derechos $i$ obligaciones en materia de Justicia se bizo sentir la necesidad de estudiarlas a la luz de la ciencia teológica, ya para el efecto de suministrar al sacerdote las reglas según las cuales debe resolver caso que sin cesar se le ofrecen en el tribunal de la penitencia, y para ilustrar a los mismos fieles acerca de la responsabilidad que puede afectar a la conciencia en las obligaciones $i$ derechos que tienen su fundamento en la lei.

Tocamos las cuestiones más prácticas e indispensables... i aguardamos que la esposición (sic) misma de las materias nos presente la oportunidad de bacerlo [la concordancia con la teología moral).

Hemos procurado siempre beber en fuentes puras $i$ autorizadas. Santo Tomás, San Ligorio, Suárez, Lugo, Molina, Benedicto XIV, Bouvier, Gousset, Scavini, Gury son los teólogos que más comúnmente hemos consultados" 58 .

La estructura del volumen distinguía cuatro partes claramente demarcadas:

Un capítulo preliminar, dedicado a las Nociones generales de la Justicia y del Derecho.

56 Ib. 280-281.

57 El capítulo único del matrimonio respondía a los efectos de la ley del matrimonio civil de 1883, y promulgada el 16 de enero de 1884. Observaba el autor del Compendio que la señalada ley estaba conforme con la definición que de ella se desprendía del Código Civil, pero "no puede ser una lei moral si se ariende a que, lejos de mirar el bien común, es atentatoria de la conciencia de la mayor parte de los ciudadanos. Mírese si no en las dificultades que ofrece su aplicación en los pocos casos que paso a enumerar", como ser aquellos católicos que nacen de un matrimonio puramente civil son incapaces de recibir el orden sacerdotal; los otros casos presentaban "situaciones difíciles de conciencia". Concluía que tales inconvenientes se hubiesen podido subsanar si "la obligación que se impusiera a los católicos de ocurrir, después de celebrado el matrimonio católico, al oficial civil para hacer constar que estaban casados, habría salvado estos inconvenientes" Cf. RoBLES (n. 29) pp. 282-283.

58 Tratado teológico-legal de la Justicia o sea concordancia del derecho chileno con la Teología moral en materia de Justicia por el P. Zoilo Villalón, de la Compañía de Jesús. Imprenta del Correo, Santiago, setiembre de 1871, "Prólogo", pp.VII-VIII. 
El Libro I Del Dominio, que abarcaba desde la página 7 hasta la 276 ,

El Libro II De los Contratos, que se extendía desde la 277 hasta la 660 .

Un Apéndice de las Obligaciones y contratos mercantiles, desde la página 661 hasta la 701 .

Este apartado, como lo indicaba su autor, era un extracto de las disposiciones que traía el Código de Comercio.

El P. Villalón dividió cada tema en dos artículos: el primero, lo que referían las "disposiciones civiles" y el segundo dando cuenta de las "cuestiones de conciencia". La minuciosidad del tratamiento dado exigiría un estudio específico destinado a visualizar las concordancias. En general, es un admirador de la obra civílista, dejando entrever determinadas reservas cuando es muy evidente el alejamiento doctrinal con lo presupuestado por el derecho canónico. Las observaciones que hemos atendido provenientes de los obispos nacionales las asume. Veamos cómo plantea su parecer en los asuntos de competencia eclesial.

En el Libro I, al hablar "Del dominio de la Iglesia" apunta:

"Se prueba que la Iglesia es capaz de dominio.

Por qué leyes debe regirse el dominio de la Iglesia.

En efecto, nuestro Código Civil acata más o menos explícitamente esta indisputable prerrogativa de la Iglesia, cuando por el artículo 586 reconoce que las cosas consagradas para el culto divino se debe regir por el Derecho Canónico, $i$ cuando por el $2^{a}$ inciso del 547 declara que no está sujeta a la regla que dicta para el ejercicio del dominio de las personas jurídicas la iglesia $i$ las comunidades religiosas, sino que se rijen por leyes especiales" 59 .

En cuanto "Del dominio de los religiosos" distingue previamente los religiosos de voto solemne de aquellos de votos simples, pero sigue el planteamiento del Código Civil en cuanto a las limitaciones de los derechos de propiedad para aquellos religiosos que han hecho votos solemnes de acuerdo a las leyes en institutos monásticos aprobados por la Iglesia ${ }^{60}$.

En esta materia, se planteó el dilema: cuando existían estipulaciones discordantes entre la normativa civil y la canónica, ¿cuál debía prevalecer?:

Villalón, P. Zoilo ( $\mathrm{N}^{\mathrm{a}}$ 59), p. 24.

60 1b. p. 33, nota 33. En el parágrafo 42 dio cuenta de los "Conflictos entre las disposiciones del Derecho Civil i la del Canónico acerca de la capacidad de los religiosos para adquirir" (pp. 35-37). 
"En abono de la lei civil podría decirse, que obra en su propia esfera cuando establece las condiciones mediante las cuales puede alcanzarse el dominio de los bienes esternos, $i$ cuando deniega a ciertas personas o cuerpos la facultad adquirirlos, $i$, por consiguiente, que es el presente caso la legislación debe estar sobre la de la Iglesia. Sin embargo, sostenemos que son válidas las adquisiciones del religioso profeso, como asimismo las donaciones que se le hagan $i$ los legados o berencias que se le dejaren; $i$ en general, que la muerte civil de que tratamos, i sus consecuencias legales, no surten efecto en el fuero de la conciencia, salvo los casos en la lei guarde conformidad con el Derecho Canónico.

1.- Es falso que siempre obre la potestad civil en su esfera cuando legisla sobre el dominio de las cosas temporales; pues según hemos demostrado en los números 29,31, el que compete a la Iglesia está por derecho divino fuera del alcance de la lei, $i$ sujeta solamente a la autoridad a que Nuestro Señor Jesucristo encomendó el gobierno de ella"61.

Como puede apreciarse, en la cuestión más crucial para la Iglesia, al tenor de la dedicación de su atención por parte del arzobispo Valentín Valdivieso, queda de manifiesto la disonancia con lo establecido por el Código Civil. De igual modo, encontraremos igual juicio, cuando trate "Del dominio de las personas jurídicas" y, con relación al artículo 547 del Código Civil, apostille que "Sobre las reglas dadas en este capítulo debe prevalecer las del Derecho Canónico, en cuanto a las personas jurídicas que sean fundación o corporación eclesiástica"62.

Como era de aguardar hubo coincidencia de criterio teológico con los restantes autores chilenos en puntuales materias, v.gr. "Del dominio de la mujer casada", donde justifica -es lícito- que la mujer, cuando el marido niega su apoyo, pueda tomar ocultamente de los "bienes sociales" para apoyar obras de beneficencia, a sus padres, pero no para hacer limosnas; o bien cuando analiza si el derecho de sucesión es de ley natural o de ley civil:

"Por concluir, parece que deducimos claramente de lo dicho: que el derecho de suceder a una persona difunta se funda en la lei natural, mas el orden de la sucesión $i$ la determinación de todo lo que a ella concierne depende de la lei civil"63.

La obra del Pbro. Eliodoro Villafuerte, Tratado Teológico de la Justicia y el Derecho en concordancia con el Derecho Chileno tomado de la Teología Moral

\footnotetext{
61 Ib. p. 30

62 Ib. p, 41.

$63 \quad$ Ib, p, 112 .
} 
del P. Gury, tenía una arquitectura análoga a la que hemos visto del Pbro. Lorenzo Robles, pero distinta en la forma expositiva: seguía el modelo de los catecismos, donde se formulaban preguntas y respuestas.

En su página preliminar leemos:

"Es de tanta importancia la doctrina católica acerca de este Tratado, que con razón los teólogos la juzgan como una de las principales de la moral, no solo porque es el remedio de los males sociales provenientes del espiritu de prodigalidad en unos, de usura y bambre de riqueza sin trabajo, con manifiesta violación del derecho ajeno, en otros, sino también porque establece el orden y la equidad en los oficios y obligaciones mutuas de los hombres, dando reglas de justicia para que pongan a salvo la responsabilidad de la conciencia ante el juicio inexorable de Jesucristo en la eternidad.

Damos principio exponiendo: 1. la naturaleza y los principios de la justicia y el derecho; 2. de la violación del derecho, 3. de la reparación del mismo, o sea de la restitución"64.

El autor señalaba que la importancia de hacer la concordancia con el Código Civil chileno obedecía al hecho que, exceptuando los de Argentina y Brasil, las restantes repúblicas sudamericanas poseían un texto legal similar al nacional: "así hemos creído prestar un servicio, no solo a los católicos chilenos, sino a todos los de la América española".

Lo didascálico de la obra se tornaba sencillo a la vez por la forma de presentar determinadas preguntas y sus soluciones, v.gr.:

“¿Se puede reimprimir un libro recién publicado o reproducir una industria en otra nación, sin el consentimiento del autor? Es probable que se puede (sic), pues todo lo que se publica para el bien de la sociedad es de derecho común. A fin de estimular a los autores de producciones literarias $e$ industriales y asegurarles la utilidad debida a su ingenio o industria, suelen las naciones establecer tratados de canges literarios e industriales $y$ otorgar recíprocamente privilegio exclusivo a los respectivos autores. Véase Gury. t. 1. N. $568^{\prime \prime 65}$.

Otra forma de encarar la interrogante apuntaba al campo de la moral casuística:

“¿Pecará el que caza o pesca contra la probibición de la ley? Hay dos opiniones de los teólogos, igualmente probables: la primera dice que no

64 Villafuerte, Pbro. Eliodoro, (n.31) p. 1.

65 Ib. 21. 
comete falta alguna, porque la ley civil, según el sentir común, es solo penal; la segunda sostiene que falta venialmente, pero sin obligación alguna de restitución. S. Ligorio. de Leg. $\mathrm{N}^{\circ} 64$ - Lugo. Disp. 6. N. 64 y otros".

En otros casos, por ejemplo, al debatir la prescripción y el requisito del título, expuso inicialmente las cuatro especies de título que establecía el Derecho Romano, y seguidamente lo establecido por el Código Civil y los principios teológicos en torno a la buena $\mathrm{fe}^{66}$.

Indiquemos que el texto se hizo cargo incidentalmente de las argumentaciones ideológicas contrarias al derecho de propiedad, muy en boga en la época en que fue redactado este Tratado, como puede apreciarse cuando atendió "De los principios generales del derecho y la justicia", y habla de las consecuencias de la privación de este derecho:

"El que injustamente usurpa un bien ajeno, delinque tanto contra el prójimo como contra Dios.

La doctrina del comunismo o socialismo que predica la comunidad de los bienes, es impía, absurda y sumamente nociva a la sociedad, porque trastorna el orden sapientísimo establecido por Dios, quita la tranquilidad pública, es de imposible realización y fuente de innumerables crimenes y trastornos sociales. Si antes clamaban, acaudillados por el famoso Proudhon: la propiedad es el robo; abora gritan: ia la tumba los propietarios!, ja ceniza y escombros por la dinamita toda propiedad! "67.

\section{ConcLusión}

La Iglesia Católica durante el periodo de la administración de Manuel Montt defendió sus prerrogativas en el marco de la institución del Patronato. Durante la década de 1850 hubo puntuales problemas que provocaron roces entre ambos poderes. La revisión y promulgación del Código Civil no constituyó para la Iglesia un tema alarmante, aun cuando tanto la época como los principios que guiaron al cuerpo legal, marcaron un rumbo liberal respecto al individuo como a la propiedad.

La Iglesia hizo sus observaciones al Código Civil desde las perspectivas del derecho canónico y de la teología moral. Basada en lo primero hizo su solicitud de modificación tardía.

$66 \quad 16,30$.

$67 \mathrm{Ib}, 4$. 
La postura del arzobispo de Santiago fue razonar desde los cambios operados en Europa -de cuestionamiento de la presencia eclesial en la sociedad, afirmación de la primacía política por sobre la espiritual, etc.- para seguidamente tratar de comprender los motivos de algunos planteamientos, si bien no claramente antitéticos con la doctrina eclesial pero sí disonantes con lo que se esperaría de un Estado católico. Hay que subrayar que las observaciones llevadas a cabo por la Iglesia, principalmente las provenientes desde la teología moral, las discurrió no solo en la formación del clero sino en sus espacios de influencia, donde los citados Tratados sobre la cuestión reforzaron las obligaciones en conciencia más que las preceptivas.

El tiempo subsanó los inconvenientes que la Iglesia encontró en el Código Civil. La justipreciación de la obra de Andrés Bello no se hizo esperar por la prensa católica:

"Tanto es el mérito de Bello como legislador y jurisconsulto, tan vasta y completa su erudición, tan profundo su juicio, tan sabias sus leyes, que aún a falta de otros sería título sobrado para inmortalizar su nombre y hacerlo por demás acreedor a esta solemne manifestación de gratitud nacional. Las buenas leyes son los lazos invisibles del orden social, abrillantan la justicia y hacen florecer la paz.

Un hábil legislador como Bello es tesoro inapreciable para los individuos y para las naciones; es un ángel de paz para la sociedad de las naciones y para la sociedad de los individuos. Por eso su nombre ha llegado a ser entre las repúblicas americanas lo que el de Solón entre las griegas" 68 .

\section{Bibliografía y Fuentes consultadas}

- Araneda Bravo, Fidel: Historia de la Iglesia en Chile. Ediciones Paulinas, Santiago, 1986.

- Arteaga, José: "Gobierno como electo y juramento civil del Arzobispo R. Valentín Valdivieso, 1845-1848", en Anales de la Facultad de Teología. Pontificia Universidad Católica de Chile, Santiago, Vol. XXVII, Cuaderno I, 1976.

- Arteaga Llona, José, "Rafael Valentín Valdivieso y Zañartu (1804-1878)", en Arteaga LL. José (Dir.), Pensamiento teológico en Chile. Contribución a su estudio II. Epoca de la reorganización

68 El Estandarte Católico, Santiago, 28 de noviembre de 1881. 
y consolidación eclesiásticas, 1840-1880, Facultad de Teología, Universidad Católica de Chile, Santiago, 1982.

- Bravo Lira, Bernardino: "Vigencia de las Siete Partidas en Chile" en Bernardino Bravo Lira, Derecho Común y Derecho Propio en el Nuevo Mundo, Editorial Jurídica de Chile, 1989.

- Caffarra, C.: "Historia de la Teología Moral" en Leandro RossiAmbrogio Valsecchi (Dirigida), Diccionario enciclopédico de Teología Moral, Traducción de Ezequiel Verona et al. Ediciones Paulinas, Madrid, 1980.

- Comisión Nacional de conmemoración de la muerte de ANDRÉs Bello: La prensa chilena y la codificación 1822-1878. Introducción y recopilación de Guillermo Feliz Cruz, Universidad de Chile, Santiago, 1966.

- Cruz, Domingo Benigno: El Clero y la Política o la participación del clero en la política, Memoria premiada por la Universidad de Chile, Barcelona, 1889.

- Fernández, Aurelio: Compendio de Teología Moral, Madrid, 1999

- Ferreres S.I., Juan B: Compendio de Teología Moral, Imprenta Eugenio Subirana, Barcelona, 1923.

: La justicia, el derecho y los contratos conforme a los principios de la moral católica y a los Códigos Civiles de España, Portugal y de las diversas naciones de la América Latina, Imprenta Eugenio Subirana, Barcelona, 1920.

- Guzmán Brito, Alejandro: Andrés Bello codificador. Historia de la fijación y codificación del derecho civil en Chile, Ediciones de la Universidad de Chile, 1982, Tomo I.

- Montt, Manuel: "Proyecto de lei sobre instrucción primaria presentado por don Manuel Montt" en Discursos, Papeles de Gobierno y Correspondencia de D. Manuel Montt, reunidos y anotados por Luis Montt, Santiago, 1982, Tomo I.

- RELACión DOCUMENTADA De LA EXPUlsión DE UN SACRISTÁN de la Iglesia metropolitana de Santiago de Chile, i DEL RECURSO DE FUERZA ENTABLADO POR EL ARCEDIANO I Doctoral DE LA MISMA, Imprenta de la Sociedad, Santiago, abril de 1857.

- Retamal Fuentes, Fernando: Chilensia Pontificia. Primera Parte. De Ṕo IV a Pío IX (1561-1878), Ediciones Universidad Católica de Chile, 1998,Volumen I, Tomos I-II-III

- Revista Católica, La: Periódico Filosófico, Histórico i Literario, Santiago, año 1857.

- Robles, Pbro. Lorenzo: Compendio de la Concordancia de la Teolojía Moral con el Código Civil Chileno en los tratados de Justicia, Derecho i Contratos. Memoria única aprobada por la Facultad de Teolojía de la misma Universidad, con ocasión del Certamen Literario del año de mil 
ochocientos sesenta $i$ tres, Segunda Edición con algunas importantes modificaciones, Imprenta San Diego, Santiago, 1896.

- Salas, José Hipólito: Comunicación dirigida al señor Ministro de Justicia por el mui Reverendo Arzobispo de Santiago i el reverendo Obispo de Concepción sobre el Proyecto de lei de organización i atribuciones de los Tribunales, Imprenta Nacional, 1864.

- Salinas Araneda, Carlos: "La influencia del Derecho Canónico en la configuración de las herencias a favor del alma en el Derecho Chileno" en Angela Cattan Atala - Alejandro Guzmán Brito (Editores), Homenaje a los profesores Alamiro de Avila Martel, Benjamín Cid Quiroz, Hugo Hanisch Espíndola, Ediciones Universidad del Desarrollo, Santiago, 2005.

: "Vigencia del Derecho Indiano en Chile republicano: la personalidad jurídica de las congregaciones religiosas", en Revista de Estudios Histórico- Jurídicos, Universidad Católica de Valparaíso, año 2000, vol. XXII, pp. 299-316.

- Salinas Campos, Maximiliano: "Notas varias sobre la actividad teológica chilena entre 1840 y 1880" en José Arteaga Ll. (Dir.), Pensamiento Teológico en Chile. Contribución a su estudio. II. Epoca de la reorganización y consolidación eclesiástica, 1840-1880, Universidad Católica de Chile, Santiago, 1982.

- Valdivieso, Rafael Valentín: Obras Científicas y literarias del Ilmo. Y Rmo. Sr. Don Rafael Valentín Valdivieso, Arzobispo de Santiago de Chile. Recopiladas por José Ramón Astorga, obispo titular de Martirópoli, Imprenta, Litografía i encuadernación Barcelona, Santiago, 1902, Tomo II. 1899-1904, 3 vols.

- VIDAl, Marciano: Moral de actitudes. PS. Editorial, Madrid, 1975, Tomo I.

- Villafuerte, Pbro. Eliodoro: El cristiano de conciencia ilustrada. Compendio de principios morales tomados de la Teología Moral del P.J.P. Gury, Imprenta Barcelona, Santiago, 1895.

: Tratado Teológico de la Justicia y el Derecho en concordancia con el Derecho Chileno tomado de la Teología Moral del P. Gury por, Imprenta Española del Comercio, Concepción, 1896.

- Villalón Aránguiz, Zoilo: Tratado teológico-legal de la Justicia, o sea concordancia del Derecho Cbileno con la Teología Moral en materia de Justicia, Imprenta del Correo, Santiago, setiembre, 1871. 